\title{
Ethnological Collections in Selected South African Museums - Past Issues and Current Challenges
}

\author{
Mathodi Motsamayi
}

\begin{abstract}
The paper examines the state of ethnological collections in two post-apartheid South African museums and is based on, inter alia, an appraisal of anthropological discourses that informed the collections. It focuses on the cataloguing of indigenous objects, which is generally inadequate and, in many cases, absent. This not only hampers the proper functioning of museums, but threatens the preservation of ancient, culturally significant items.
\end{abstract}

In this context, a discussion of the artefacts' background would be of importance to establish their origins, the motives for their presence in collections, and their current state. Presently, however, such information is difficult to obtain, since persons who have knowledge regarding the makers, donors and collectors of artefacts are no longer part of the museums' establishment. Besides, many ethnological collections result from fieldwork trips by anthropologists and persons with an interest in ethnology but, sadly, many of their contributions lack identification and other pertinent information. Anthropologists, museum workers, and donors who have contributed to the presence - and, hence, survival - of artefacts in social history and cultural history museums have failed to provide them with tangible records. With only patchy information available, it is evident that present curators face a huge challenge in cataloguing such materials so that they can be better preserved and further researched.

Using postcolonial theory to provide a critical analysis of the current situation, based on available archival records and unstructured interviews with museum officials and researchers, I contend that the lacklustre manner of assessing items of indigenous material culture in museums of ethnography, and the accompanying decontextualization, are irreconcilable with their original socio-cultural and environmental significance, their meanings and technological trends. The question is how to reverse this neglect of collections of rare indigenous material culture so as to arouse the warranted interest of local and wider audiences and restore the connection with indigenous histories that in the colonial and apartheid era have been ignored and deemed irrelevant to the 'grand march of Western historicism' (McClintock 1994: 292).

Key words: Anthropology; decolonization; decontextualization; ethnological collections; Iziko museums; Polokwane Cultural History Museum; post-apartheid; South African museums; vessels.

\section{Background of the study}

In South Africa, many ethnological collections of artefacts produced by Africans are 'housed' by heritage institutions, but the care expanded on the objects consists mainly in placing them in storeroom facilities where they are distant from custodians, devoid of identifying material, and not, or insufficiently, researched. This study explores ethnological collections in two 
museums in South Africa, the Social History Centre (IzikoSHC), which is a part of the Iziko Museums in Cape Town, Western Cape Province, a large, former white and privileged heritage institution, and the Polokwane Cultural History Museum (PolokwaneCHM) in Polokwane Local Municipality, Limpopo Province, a smaller regional museum in a rural province where three former Bantustans were located, namely Gazankulu, Lebowa, and Venda.

The Polokwane Cultural History Museum is home to a collection of ethnological material, most of which is kept in storage rooms. Polokwane in the Sesotho sa lebowa language means 'place of safety'. The PolokwaneCHM is housed in a building also known as Irish House Museum. An earlier structure in the same grounds, built in 1886 by August Julius Herman Moschke, a German, was used as a general merchandise store. In 1920, the building came into the possession of James Albert Jones, who named it Irish House, after his homeland. He sold Irish House in 1984 to the Polokwane City Council who made it into a local museum (Polokwane Museums ca. 2014).

The other material culture collection featuring in this study is in the South African national flagship museum of IzikoSHC. The name Iziko is of isiXhosa origin and means 'hearth'. The roots of the Iziko Museums are found in the South African Museum, established in 1825 (Summers 1975: 5) by Lord Charles Somerset, a British colonial administrator. Most collections in the Centre date from the nineteenth and early twentieth centuries when historical, archaeological and ethnographic collections were housed in the South African Museum (SAM), later renamed South African Cultural History Museum and Iziko Museums.

From the above it is clear that the museums in question are products of the colonial and apartheid eras (Kgopa 2003: 11; Strydom [2017: 7). They house rare indigenous African material culture, such as baskets, wooden and pottery containers, and other utilitarian containerforms to which I refer, collectively, as an ethnological collection. My focus is specifically on dung vessels (Difalana) as an example of neglected material culture.

Those researchers who worked in these museums during the apartheid era and who are still alive are no longer part of these heritage institutions, as a result of which it is difficult to catalogue and identify certain artefacts, for example the ancient dung vessels known as Difalana. Often, collectors have left no field notes. According to one museum official, no exhibitions are presently organized and damaged artefacts are not restored due to a lack of resources and expertise. Since 1994, no traceable donations or purchases have been recorded in the IzikoSHC and PolokwaneCHM where I have conducted ethnological research of dung vessels. New staff members in post-apartheid museums do not have enough information about the various material cultures in South Africa to attempt the cataloguing and exhibiting of artefacts. Cataloguing refers, 'in the context of $\mathrm{CCO}$ (Cataloguing Cultural Objects), to the compilation of information by systematically describing the works (...) in a collection' (Baca et al. 2006: 375).

In European museums discussions concerning African artefacts have focused on the return of artefacts appropriated during the colonial era (Van Beurden 2012; Scott 2019), rather than on providing these objects with a contextualizing background in order to determine their true origin and meanings in Africa. Recently, debates on cultural history museums have been dominated by questions raised about anthropological collections (Lonetree 2009: 322), popularized as ethnographic collections that were created mostly in the colonial era, with the aim of reaffirming the rural and 'tribal' notions that generally were associated with 'primitive' African people. In museums where collections listed as anthropological material are housed - including primarily ethnological items of non-Western origin - these were regarded as belonging to 'the other'. Without adequate information and a detailed catalogue (Burcaw 1997: 93), some artefacts are exposed to a variety of external and internal risks, for example a loss of interest due to the recent mass production of commodities that fulfil the functions of traditional objects, and the loss of habitat, raw material and knowledge that is used to determine their construction. Thus, today artefacts remain undocumented because of a lack of resources and accountability.

I strongly suspect that there are, in addition to the two museums under consideration, other institutions in South Africa where valuable collections of material culture are housed, which are suffering from a serious lack of supporting information and are not the subject of any relevant research. In order to fulfil their public roles, museums not only need to review 
the status of, and information on, heritage objects in their collections, but also to revise their accession policies, for example, with a view to awakening the interest of surrounding communities (Schmiegel 1988; Weil 2000). I explore in this paper some of the factors preventing museums from addressing the challenges posed by housing these special collections. My aim is to suggest ways to improve the handling and managing of rare items of material culture on the basis of information gathered from museum officials and outsiders. In both institutions the vessels are undocumented and kept in storerooms.

\section{Table A}

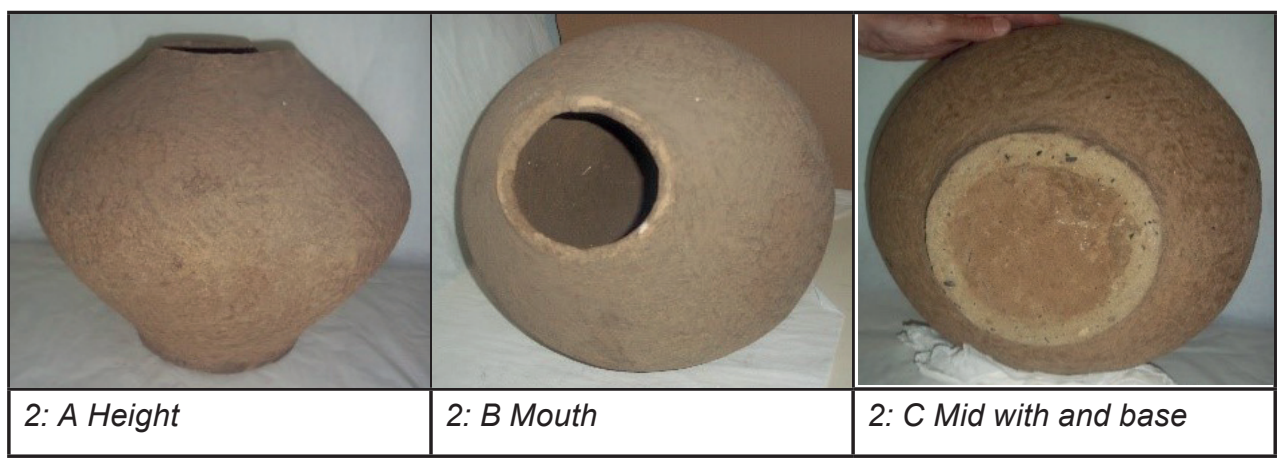

Figure 1: Maker unknown (not recorded). 1962. Spherical Sefalana with extended base. Collection: Iziko Social History Centre. Accession number UCT 35/16. Height $33 \mathrm{~cm}$, mouth $17 \mathrm{~cm}$, mid width $38 \mathrm{~cm}$ and base $18 \mathrm{~cm}$. Collected by Professor Isaac Schapera. Photograph by the author. 2014.

\section{Table B}

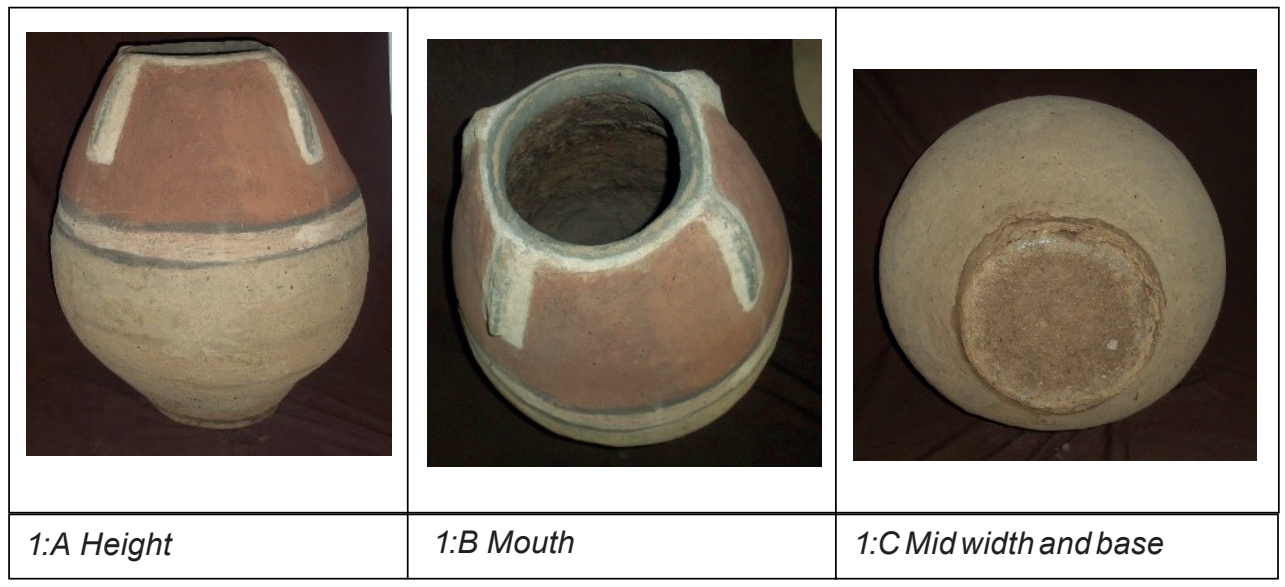

Figure 2: Maker unknown (not recorded). 1980s. Decorated Sefalana. Ovoid form with a narrow opening. Collected in Polokwane areas, South Africa. Collection: Polokwane Cultural History Museum. Accession number (n/a). Height $72 \mathrm{~cm}$, width $42 \mathrm{~cm}$, mouth $23 \mathrm{~cm}$, base $23 \mathrm{~cm}$. Collector not recorded from Polokwane Cultural History Museum. Photograph by the author. 2014. 
The above examples taken from ethnological collections (tables A and B) are rare, undocumented dung vessels known as Sefalana (singular); Difalana (plural); 'granaries' used to transport and store agricultural products. The oldest studied Sefalana vessel is found in the Iziko Social History Collections, Cape Town, while another set of old Difalana vessels is present in PolokwaneCHM. Difalana vessels technically connect people living in South Africa and Botswana and can be used to advance the study of objects of material culture and past agricultural practices. At both the IzikoSHC and PolokwaneCHM the identity of the makers of Difalana is unknown, as the collectors left no informative records made during their expeditions to areas where they found the artefacts. In the Polokwane area today, and some regions of Botswana, women potters make innovative versions of ancient Difalana vessels for tourist purposes, restoring links with the cultural past of their communities.

While dung vessels are a major example of my research in the ethnographic storerooms of the IzikoSHC and Polokwane $\mathrm{CHM}$, I found that their inadequate or non-existent documentation is by no means an exception - the same also applies to beadwork productions, wooden objects, metallic objects, woven fibre basketry, ceramics and other artefacts. All of these require research which could possibly lead to identification and to ensuring that their conservation is pursued in line with contemporary preservation practices of African artefacts. I would like to emphasize that collections kept in the storerooms of various museums have a special place in my research, which deals with the oldest examples of material culture that I have come across in South African museums.

\section{Research approach and methods}

My research involves the use of archival records in museums and fieldwork consultations with heritage practitioners and museum workers, in order to get first-hand information on the situation. It was extremely disconcerting to discover gaps in the archival, institutional records documenting collections, both in rural areas and in the Iziko national flagship heritage museums where representative collections of ethnological materials are housed. Collections of artefacts consisted of objects, photographs and human remains, the latter being a thorny issue in South Africa.

My visit to the museums featuring in this paper exposed the inadequacy of systematic records and the lack of proper methodological contextual documentation relating to indigenous material culture, while online data provided by international museums proved unhelpful. Appraisal of current museum methods of cataloguing (Case 1988; Delsey 1989; Hunter and Bakewell 1991) shows entrenched formal categorizations of cultural heritage, whereby cultural objects are infused with the dilemmas of decontextualization and misinterpretation. Decontextualization in relation to cultural objects means, '(...) to describe what happens to an artwork when its context or value has been removed or transferred to another non-art object'. ${ }^{1}$ Based on inter alia problems of decontextualization, I argue that there is a need to develop practical ways of improving the interpretation of African cultural items kept in South African heritage institutions that are, alas, neglected and forgotten.

During my studies I have become familiar with the problems involved in attempts to update the documentation of ethnological collections in South African museums, given the availability of scant, and often dated, scholarly information on artefacts. To come to an assessment of the present situation in institutions housing South African material culture, I rely on qualitative research methods. According to Punch (2005: 56-7), qualitative empirical materials include '(...) interview transcripts, '(...) interview transcripts, recordings, and notes, observational records and notes, documents, and the products and records of material culture, audio-visual material, and personal experience (such as artefacts, journals, diaries and narratives)'. I use empirical materials in order to obtain relevant information about the background of ethnological collections kept in the museums under discussion. I also peruse records of previous researchers of material culture to identify possible missing information (Lawton 1967; Jordaan 1992). For data analysis, I applied narrative analysis. As museums 
are contested areas, I use unstructured interviews to acquire information about ethnological collections from different museum officials (one mixed-race woman, one white woman, two white men, three black women and four black men) including past employees of these institutions. According to Bernard (2006: 213), 'Unstructured interviewing is excellent for building initial rapport with people (...) (and) for talking to informants who would not tolerate a more formal interview'. To consider the historical and contemporary meanings of items of material culture in museum collections and communities is a worthwhile endeavour. This research intends to highlight a more contextually relevant approach to deepening our understanding of collected cultural artefacts. South African heritage institutions have always faced challenges in dealing with ethnological material. These challenges continue into the present time in that many museums are not performing adequately in terms of advancing the research of material culture and attracting audiences to view exhibits, although they are expected to function as institutions or agencies for the development of culture and nationhood (Edson 1997; Rassool 2006).

\section{Theoretical underpinning and museum discourse}

My study is theoretically grounded on the critical application of post-colonial theory. In research projects, theories enable a researcher to develop concepts and juxtapose and validate findings. Hence, discourses on decolonization inform the present study which aims to better contextualize the prevailing status of museums. Elements of apartheid and colonial legacies still dominate South African communities and their heritage institutions, many of which were designed to create and sustain systems that would allow colonial perceptions to flourish and replace local traditional structures that had existed for many years (Motsamayi 2018: 87).

McClintock (1994) notes that colonial domination entailed the systematic interference of rulers in the capacity of appropriated cultures to organize their dispensations of power. In relation to material culture, Wa Thiong'o (1994) understands colonization as a process involving the destruction and deliberate undervaluing of people's history through the adoption of the colonizers' language. Thus, in Africa, colonization aimed to control peoples' commodities, including what they produced, how they produced and how they distributed the products of their making (Wa Thiong'o 1994: 442). To further these goals, the colonial powers and the apartheid government, modelled on Western concepts of power distribution, established a type of patronage in heritage institutions that, after independence, allowed for their legacy to be continued in respect of the administering of African artefacts. Recent events, such as the \#RhodesMustFall protests by students around the country, express the wish to expunge memories of a past South Africa (Chikane 2018: 25; Drayton 2019: 2), manifest in public monuments, educational institutions and in museums, repositories of artefacts that represent a collective social and cultural memory.

The ICOM Code of Ethics (2006), under point 2.20, concerning the documentation of collections in line with ethical considerations, states that, according to accepted professional standards, documentation should include 'a full identification and description of each object, its associations, provenance, condition, treatment and present location'. The data should be kept in a secure environment and be supported by retrieval systems that provide access to the information by museum personnel and other legitimate users.

South African museums urgently need to alter their outlook and turn to accommodating various cultures. In rural areas such as Limpopo Province, museums play a less active role than institutions in urban areas, for example the Western Cape. Former white and privileged heritage institutions have the best facilities in museums as well as the use of human resources. After the first democratic elections, this example has been followed by South African national museums, many of which are located far from the cultural groups they are supposed to represent, so that it is difficult for the custodians of collections to regularly visit them (Motsamayi 2018: 244). In fact, museums in South Africa have historically been strongly contested areas and continue to be so in the present. Discourses in the context of a transforming South Africa continue to impact on the functioning of museums. Increasingly, museums have been developed into institutions accessible to everyone, irrespective of background. That static notions of museums are replaced with more flexible approaches is undoubtedly a positive development. An enduring problem, however, is that museum collections, which hold items of importance but lack relevant information, fail to arouse the interest of a wider audience (Hodder 1996; Golding 2009). 
In documenting an ethnological collection, it is vital to explore the social functions and indigenous meanings of artefacts. In many black communities, the concept of collecting artefacts from different areas and putting them on show was unknown, except perhaps in the case of traditional healers or of rulers who arranged received gifts in their homesteads, although without the intention of presenting them as art. Such objects might also have been acquired through barter exchange and have the potential for further exchange. One key area - also the basis of my theoretical framework - is the need to deconstruct the ways in which so-called historical meanings of indigenous material culture have been compiled, as argued by McClintock (1994: 292). The South African Museum Association's Pietermaritzburg declaration of intent states under point 4 that 'all South Africans be encouraged to express openly their views as to how the country's museums may better serve the interests of all in South Africa' (Coombes 2003: 300). The general aim is to broaden understanding and to attain more holistic perceptions of the material culture of African people. This could lead to the surfacing of new, detailed information on how people's creativity has been shaped in relation to their surroundings. Adequate research of ethnological collections, from the perspectives of science and social science, may unearth information that reveals the full historical and sociocultural significance of artefacts, supporting validated knowledge on ethnological materials.

\section{Contested aspects of museums}

Museums preserve objects of African material culture that may reflect the cultural connections linking many different ethnic groups (Corsane 2004). For example, the PolokwaneCHM was created by the apartheid government in the Polokwane area specifically to promote local culture, but ended up housing cultural objects of multiple origins. Most of the collections in the museums under discussion have not been collected directly from the communities among which they are kept today. The IzikoSHC collections are sourced from nine South African provinces and from outside the country, but still depend on the respective museum's mission statement. South African national institutions house collections of international standing. In neighbouring countries, there are several cultures whose artistic productions share characteristics with South African local heritage objects and, for information pertinent to their cultures, they turn to South African museums.

Countrywide, museums are divided into national, provincial, district and regional museums and each of these serves particular purposes. A few have the potential to undertake research studies in respect of artefacts in their custody, but their lack of African researchers with knowledge of local languages in which to communicate with community leaders makes research problematic. Some museums have developed links with research institutions such as universities, where consistent research can be conducted. At many universities, the anthropology departments that used to be major collectors of socio-historically important African objects are presently not actively involved in (a great deal of) research on African material culture. Some university collections of indigenous artefacts have been donated to public museums. There are other universities, however, that try to enrich their disciplines by developing new insights and knowledge, while presently leaving actual research in the field of material culture to museum workers who apply selective analysis approaches to generate new detailed information relevant to the discipline. In the meantime, academics remain active participants in research conducted in museums across South Africa, whereby they function as catalysts. Through their research projects, they activate information available in museums which allows the museums to develop, build on and interpret new information generated by the research which the museums can then use (Coombes 2003; Dubin 2006). Regrettably, most historically significant sample material in public collections is not, or is inaccurately, documented.

Finch (1988: 146) states that the original intention of establishing museums was to remove artefacts from the context of their ownership and use, in other words to remove objects from their circulation in the world of private property, and introduce them into new environments where they take on different meanings. Thus, ethnological objects lost their original meanings at the very moment they were collected and separated from their domestic use to become part of a museum collection and end up in a storeroom. When artefacts are acquired by a 
museum, their significance, both as a separate object and as part of a collection, depends on the cultural position into which they are categorized (Kreps 2011; Onciul 2015). Brain (1980: 231) observes that most African (art) objects carry symbols and designs that convey specific meanings. Once objects are publicly displayed in a museum, a wide range of meanings can be ascribed to them (Csikszentmihalyi and Rochberg-Halton 1981). They may, for example, be used to generate insights into what they were used for (Hodder 1996: 12).

In the past, museum visitors have generally belonged to a specific interested group (Finch 1988: 147). This situation is still fairly prevalent today, due to South Africa's history of black people being excluded from museum activities. African governments have so far failed to come up with plans to bring black people aboard in efforts to promote art in a museum context (Coombes 2003: 206). Thus, knowledge production based on indigenous collections in South African museums continues to be structured according to historical demographic dogmas aimed at promoting ideologies which are no longer relevant to black people and the country as a whole.

Museum exhibitions represent the nature of a society by using research to produce meanings and knowledge about artefacts in specific ways which can be unravelled by posing pertinent questions such as why a display is presumed to be worth looking at, and what information about displayed objects and their background is offered to audiences (Pearce 1994: 241). As yet, there has never been a catalogue exhibition in any South African museum that focused on ethnological collections from Limpopo Province. Presently, some of these collections are becoming increasingly difficult to catalogue, as the functions and meanings of artefacts have changed to accommodate producers' current needs (Jordanova 1989; Westermann 2005). In the two museums I have surveyed, most ethnological collections were left in storage facilities, solely because exhibiting them without the provision of informative details would be an unsatisfactory exercise (Ames 2004). As a result, the public is generally not aware of the presence of such rare objects in cultural institutions.

\section{Discourses on 'collection in between' in post-apartheid museums}

The present section is concerned with some results of my reading of anthropological studies that have informed theoretical frameworks associated with the design of an adequate cataloguing model for objects of indigenous material culture in South African museums. In this context I refer to ethnological collections as 'collections in between' (meaning that they were collected in the apartheid era for ethnological purposes whereas, in post-apartheid South Africa, museums are yet to position, and define the purposes of, collections in their care).

The ethnographic objects gathered by anthropologists, twentieth century travellers, and researchers have resulted in extensive collections of material culture that offer exciting opportunities for research. I reiterate that these collections have been largely ignored by researchers and local heritage institutions and are, as a result, practically absent in contemporary accounts of South African cultural legacies. Mid- to later-twentieth century Modernist studies of indigenous material culture (Schofield 1948; Lawton 1967; Jordaan 1992), as well as collections in South African museums, fail to cover key issues about indigenous material culture. I postulate that there is a need for a broader examination, conducted from African perspectives, of professional museum practices such as cataloguing, display and documentation of indigenous material culture. Preparing for contemporary digitization must also be taken into account.

Referring to ways in which anthropologists created ethnological collections that are now in museums, Llobera (2003: 10) writes that, 'Bronislaw Malinowski was the true creator of the ethnographic revolution in anthropology'. Thus, an understanding of ethnography is necessary for grasping the motives of anthropologists collecting African objects. Fox (1994: 129) notes that ethnology means, 'the detailed description of particular people'. Llobera (2003: 7) adds that two different aspects of the discipline used to be distinguished, namely ethnography and ethnology. In the American understanding, ethnography is concerned with the first-hand fieldwork conducted in a community, whereas ethnology studies the results of ethnographical fieldwork, to theorize or to generalize it. The term ethnology is nowadays rarely used. In the British tradition, ethnology entails the reconstruction of the history of one 
or more groups in a given area. In the 1960s, in continental Europe, this comparative study of societies and cultures came to be called social anthropology or cultural anthropology. Ethnology in the Germanic and Scandinavian tradition referred to the study of specific people (Volk) or to minorities (Llobera 2003: 7).

The interpretations of these different approaches were applied interchangeably in the collection of African artefacts in South Africa, implying that most collections and displays of indigenous objects were created from Euro-American viewpoints (Blench 2006: 37). In museums, the identification of objects by describing them in unspecific ways added up to a practice of arranging them into categories (Pearce 1994). The moment that objects were placed into categories, their meaning was constructed (Knell 1994: 53). In that case, the cataloguing of an object consisted essentially in ensuring that it fulfilled all the criteria for fitting into a specific category. However, to analyze an object in relation to a conceived category may necessitate its division into forms and, sometimes, ignores original features that might indicate what the object, as seen from the producer's cultural perspective, stands for (Pearce 1992). In the interpretation of an object from an anthropological viewpoint, attention tends to focus on living traditions that are, in fact, subject to change. The above remarks represent parts of ideal anthropological considerations and suggest the need to revisit aspects of perceptions of artefacts that did in the past, and presently continue to redefine objects and their continuous social meanings.

\section{South-African museums and their un-decolonizable aspects}

Debates about the decolonization of South African museums are characterized by controversy (Dubin 2006: 4), partly because museums do not belong to traditional African culture. Selected museums were built before the dawn of democracy and continue to reflect Western traditions, while their role in relation to Africa consists mainly in the housing of African material culture. Another past function of these institutions was to promote colonial and apartheid ideologies. In spite of these limitations, some museums have contributed significantly to the preservation of African artefacts that, in the colonial era and during apartheid, might otherwise have been lost forever. At the same time, museums remain contested areas of cultural production (Karp 1992: 6). South African museums have been established specifically to promote the cultures of certain groups and ideologies but, due to the locations where they were built, these institutions generally fail to reach their goals. In South Africa, as a consequence of African traditions being interpreted in colonial contexts, interpretations of material culture productions are always coloured by subjectivity. Based on the above arguments, it is possible to deconstruct historical anthropological stereotypes and assumptions regarding collections of artefacts, specifically in reference to ethnological collections housed in South-African museums. I am of the opinion that insights resulting from past colonial assumptions need to be debated and reconstructed, so as to accommodate contemporary discourses that redefine misconceptions (Mignolo and Walsh 2018).

There is currently significant global interest in the decolonization of museums (Motsamayi 2018: 122). With the help of post-colonial theory, as proposed by Fanon (1961), Memmi (1991), McClintock (1994) and Césaire (2000), it is vital to deconstruct assumptions about African artefacts dating from the past, in an attempt to logically support a cataloguing model that includes such artefacts and provides a sense of their origins, in particular their links to ancient traditions, while also considering their contemporary state. McClintock (1994: 293) describes the reluctance of post-colonial theory to view the world in terms of a singular perspective. In accordance with this approach, in this context the term 'post-colonialism', as it occurs in my analyses, should not only be understood as challenging the legacy of apartheid in the documentation of indigenous material culture since the introduction of colonial anthropology, but also as referring to whatever has taken place in Africa by the earliest scholars and travellers with various colonial motives.

Addressing the legacy of colonial systems, McClintock (1994: 292) posits that postcolonial theory aims to challenge the 'grand march of Western historicism' and its notions of 'them and us' and 'othering'. In South African museums, the main reasons for collecting African artefacts included colonialist objectives, propagated by administrations in British colonies 
and by the apartheid government. Colonial and apartheid rulers did not encourage relevant research on ethnological collections beyond ethnographical activities. In order to secure their ideological fingerprints, colonial systems supported people in Africa who followed their orders and, indeed, to some degree colonial cultures were accepted by the masses. Those individuals who could successfully communicate the colonial message to ordinary people and functioned, one might say, as colonial agents, were rewarded with privileges that enabled them to operate efficiently (Cabral 1994). This description fits many anthropologists operating in Africa during the colonial era (Hammond-Tooke, 1997). The process was influenced by the ways in which colonial operations - above all the impact of industrial Western society (Mignolo, 2007) - shaped societal structures in Africa (Collins 2017). Legacies of apartheid and colonial systems that operated extensively in Africa still prevail in institutions, languages and forms of creativity adopted from the colonizers.

Links formed with museums in the past have created a dependence that prevents former colonized societies from developing their own systems freely and without borrowing from colonial prototypes. Memmi (1991: 276) describes the bond between colonizer and colonized as potentially destructive as well as creative. It may destroy both of them before recreating them into colonizers and colonized. The institutions where the material culture collections are housed provide little relevant information and, as a result, the original identities of artefacts are compromised.

In South African museums, the names of many indigenous objects for which their collectors could find no Western equivalents have been changed. Most current museum curators have no knowledge of the communities where objects originate and, hence, cannot identify them in a meaningful way. In museums these artefacts are, in short, described from a Western perspective (Motsamayi 2018: 24). This generally characterizes the foundation upon which collections of work created by 'the other' were built. To uncover information that is needed for cataloguing artefacts in heritage institutions, the historically determined situation of museums has to be deconstructed.

Sadly, most ethnological collections in contemporary museums have never been exhibited and catalogued, which complicates efforts to understand and describe the objects originating from, and relevant to, the local traditions that produced them. Instead, they remain locked up in storage rooms. Scholars may have followed this practice in order to validate their research as useful for colonial administrative institutions that aimed to advance colonial rule by creating an understanding of local communities (Giblin et al. 2019: 472). Part of the problem is that museums are based on traditional Western theories of knowledge and aesthetics (Jeffers 2003: 110). When interviewing participants in my research, I had to explain to many heritage experts that museums are Western institutions. However, older people in rural areas were perfectly aware that museums are not part of their culture and wondered why museums keep their artworks. The role of museums should entail the collecting and preserving of objects, encouraging research and gathering data, exhibiting artefacts, and functioning for the benefit of communities.

The results of colonial history have contributed to the shaping of ethnological collections over which Africans at the time certainly had no control. In many African states, there have been ongoing discussions since independence about replacing colonial systems with institutions organized along the lines of indigenous ideologies. In essence, however, the struggle for freedom doesn't always lead to a return to authentic national cultural practices (Fanon 1994). In South African museums and other heritage institutions, the end of apartheid has also not led to a change in the cataloguing of African artefacts. Several classifications are still gender-biased and inconsistent with contemporary discourses about museum collections and gendered perceptions of power relations in institutions that, in the colonial era, favoured males over females (Motsamayi 2018: 208). At the same time, it should not be overlooked that ethnological collections currently in museums would not have been preserved without the existence of Eurocentric institutions where African artefacts, many of them produced by women, were collected. In spite of this, even today the majority of collectors and keepers working in established museums are not black women. Because of the socio-historical background of material culture, it is often males and institutions that have the power to determine the classification of, inter alia, collections in the custody of museums. The world at large has, in 
the past, perceived South African material culture as somewhat remote (Coombes 2003). Hence, the future of local institutions looks less promising than that of similar institutions in other developed countries, where systems function for cataloguing artefacts without the intrusion of prejudicial gendered concepts.

Museums should focus on adopting decolonizing approaches for dealing with objects that have been in their care, but neglected, for years (Onciul 2015). The concept of the museum may not be African, but the artefacts in these institutions reflect their African identities and that is where ideas for decolonization should start. In my view it will prove impossible to decolonize South African museums if artefacts are not decolonized through research and public exposure. During their expeditions in rural areas and villages collectors apparently did not take down much information beyond a few ethnographic notes that are now present in the museums. Follow-up research has not yet been undertaken and there have been few attempts to trace traditions associated with objects of material culture. Although some collections are inalienable and will therefore remain in museums, their ownership is becoming a hotly contested topic and representatives of many groups may claim to be the true custodians of such collections.

In museums in Limpopo Province, for example, no researchers were actively involved in studies aimed at the cataloguing of ethnological collections based there, nor was there any other ongoing research associated with the collections, although these have been present for a long time, especially those in the PolokwaneCHM. This state of affairs is also common in museums in other rural provinces. In contrast, the IzikoSHC in Cape Town has well organized staff and management structures. Some employees have several research publications to their name and the museum is increasing the numbers of both international and regular local visitors. In addition, staff members have extensive experience in organizing museum activities, based on facilities they have inherited from the apartheid administration. In discussions with officials in both museums, I realized that perceived inequality is a major reason why poor people don't visit museums regularly. While South African museums are generally located in urban surroundings (Tietze 2017: 166), some are far removed from the communities they are meant to serve. The result is that these communities have little interest in visiting the institutions that house their heritage collections. In addition, it is obvious that poverty and entertainment choices pose a powerful challenge to the creation of a keen museum audience. Poor people from rural areas and townships are not easily inclined to visit museums and rather focus on the practical issues of their daily lives. Some efforts have been made to introduce mobile museums. Colonial spatial planning in relation to heritage institutions has led to a model in which various persons participate, each of these following his or her specific interests, based on class and race (Goodnow et al. 2006).

The museums that are part of my research - PolokwaneCHM and IzikoSHC - were inspired by colonial and apartheid ideologies, including their perceptions of what constitutes indigenous cultures with their supposedly static nature. In this context the 'levels' or 'stages' of native civilisations were determined on the basis of evolutionary theories (Lonetree 2009). The institutions were not established for the general public. Few people could afford to live in, or travel to, urban areas. In Cape Town, a person living in Hout Bay or Table View usually belongs to a black elite or is white and is able therefore to access the Iziko museums. For black people living in, say, Imizamo Yethu, Mitchells Plain, Lavender Hill or Guguletu, it is much more difficult. The same applies to the Polokwane museums. An unemployed person in Ga-Dikgale, Seshego or Westernburg has to travel to Polokwane to visit the PolokwaneCHM, but the black and white elites residing close to Polokwane city can pay regular visits to the museums. Hence, the accessibility of museums also depends on the spatial planning of their sites in relation to the public they are meant to serve.

\section{Finding a place for the neglected 'collection in between'}

Many South African museums built before, during and after apartheid are key institutions with an international reputation. They can be used to connect visitors with past and present by organizing activities that are relevant to human beings, whether their homes are on the African continent or elsewhere. Unfortunately, however, the lack of effective cataloguing systems in many South African museums leads to a loss of meaning for their artefacts and prevents their exhibition. 
As Pearce (1994) remarks, objects in museum collections can generate knowledge of historical, economic and scientific value, provided they are supported by detailed information that is based on scholarly studies and offers audiences a broad insight. As teaching institutions, museums are tools of discovery and preserve cultural and historical identities (Ashworth and Howard 1999: 101). Hooper-Greenhill (1999: 13) argues that people who share common goals can, depending on their relationship with the past, interpret their identity by trying to understand the meanings of artefacts. Museum collections may be regarded as artistic creations of self out of self. They can connect people with past and present and offer hope for creating a future (Pearce 1992: 66). Societies are to a degree defined by collected materials, displayed and preserved in museums and their storage rooms. South African museums are supposed to operate in conjunction with the communities in which they are located. As Ashworth and Howard (1999: 83), on the other hand see it, the museum has become an instrument for communicating ideas to societies. By implication, the South African museum can be identified as a reinvented, originally Western, concept that has been adopted by Africans and that, by now, has become local tradition, serving to preserve and present African cultures.

In contemporary society, museums preserve a country's cultural treasures for posterity, stimulating an awareness of past, present and continuing traditions, and sometimes inspiring their revitalization. Motsamayi (2018: 249) notes that culture shapes people as characters and as individuals who belong in the culture concerned. Some abandoned and forgotten cultures are today reinvented for museum purposes. Without museums, some cultures and their practices - or their memory - might not have survived to this day (Thomas 2016).

In museums, audiences gain knowledge of what has shaped their communities in the past and are exposed to other material cultures in what becomes a continuous process of learning (Vergo 1989; Karp et al. 1992). My research has taught me the need for a passionate interest in artefacts in museums and for studying their connection to their cultural backgrounds in order to develop an understanding of their traditional local meanings. Officials in one smaller museum I visited told me that there has been an exodus of experienced staff members who have left and have not been replaced by equally experienced persons. Poor funding by governments exacerbates the situation. No museum journals are being published, no museum website is being established, and potential visitors are not updated in respect of activities taking place. In addition, there is no attempt to catalogue artefacts, except by a few interested academics and by persons who have an interest in tourism.

In the African context, the makers of artefacts were, in the first place, fulfilling their roles as members of communities and only thereafter motivated as creative individuals. Culture among Africans is not characterized by individualism. Mostly, Africans stress in their artistic expressions a holistic creativity. The ownership of cultural practices is collective rather than personalized (Gell 1998). In the past, creativity was not driven by a wish to make a profit as it appears to be today. Even information on how collections were acquired is not available in most museums, due to the fact that collectors have collected them for particular purposes, for example for the extraction of ethnographic data, rather than for display or research.

\section{Concluding remarks - cataloguing and documentation}

Research of this nature is likely - and meant - to raise other issues related to indigenous material culture. It is therefore important to develop effective systems of documentation, countering years of neglect and supporting current scholarship. Getting into direct contact with descendants of producers of material culture in rural areas may advance knowledge and the preservation of creative traditions. It seems unlikely that, after my research ends, there will be any further study of indigenous vessels in these museums. South African museums obviously face serious challenges in respect of cataloguing their collections and, currently, they have no plan that is specifically designed for dealing with and cataloguing cultural objects, nor are they preparing to attempt digitization in the near future.

For museums to function optimally and to attract the public, collections have to be made accessible by registering every artefact as fully as possible (Bennet 1988). South African museums follow different methods for deciding which objects to accept as part of their collections and how to handle them. Museums should develop cataloguing systems or ways 
of documentation that will accommodate their artefacts, focusing on accessioning objects, including information on how they ended up in a museum, as well as making suggestions for their preservation (McKenna and Patsatzi 2005; Baca et al. 2006). Currently, with artefacts being kept in storage facilities, there is little way of knowing whether they have been accounted for or are generally neglected, for the sole reason that they do not fit easily into contemporary museum structures and in the artistic hierarchy of the past that, to some degree, continues to dominate in the present (Grimshaw 2001). During my fieldwork I found that many museums in rural areas cannot afford to research artefacts for museum purposes, because the provision of funds for museums, as compared to the financing of community empowerment projects, is not seen as a priority by many rural municipalities.

The adequate cataloguing of indigenous vessels is important because without proper records artefacts may go missing or their existence be forgotten (Motsamayi 2018: 3). Due to the lack of a proper cataloguing process, some vessels in museums are neglected and in a state of deterioration. Nor have academic institutions effectively addressed this problem. Some heritage institutions operate entirely independently from other such structures, focusing exclusively on their provincial and regional level. I found that in cataloguing and documenting collections, each museum has its own preferred method, often without a computer system. Researching ethnological collections, I had to travel widely, trying to locate specific objects. Some cataloguing models are applied to the collections of just a single specific museum, as it suits the institution's available resources. This results in every museum documenting its collections in its own way. Museums that cannot draw audiences may also fail to generate an income, so that they cannot buy new artefacts and grow their collections, while there is as yet no developed culture of ordinary South Africans donating objects to rural museums. Many people sell their artefacts to tourists (Graburn 1976), rather than giving them for free to a museum. Compared to museums in rural areas, most collections in urban heritage institutions consist of donations made by wealthy persons, academics and various institutions, hoping that the gifts will be acknowledged in the display, even though the names of the actual producers of such artefacts mostly remain unmentioned. Surprisingly, in the description of an object, the names of donor and collector are given priority over the identity of its producer. In their efforts to decolonize their institutions, many museums are faced with the above-mentioned obstacles (Bennett 2004: 3). This ethical issue needs to be addressed in the cataloguing of ethnological collections.

Accessing an object in the museum context entails following the formal process that was adopted to accept and record it as belonging to the museum's collection (Buck and Gilmore 2007). During my research, I found no evidence of any such process being followed in PolokwaneCHM and IzikoSHC. There is no record referring to Difalana vessels, except cards to identify them in storage spaces. Some collections in museums have been donated and donors are not even acknowledged. The lack of such information complicates the proper identification of artefacts and obscures their historical contexts.

My comparative studies in urban and rural South African museums have made me realize that the various cataloguing models used world wide (ICOM 1996) cannot satisfactorily contribute to an understanding of Southern African ethnological collections and need to be re-considered. One model used by museums is the nomenclature system, although it is applied by some museums in an unconscious fashion. In Chenhall's description (1988: 1), the nomenclature model involves a structured list of terms organized into a classification system to provide the basis for indexing and cataloguing collections. The nomenclature system allows holders of collections to share data with the broader community and provides ways to solve problems presented by computerization. In my view, computer-based nomenclature cannot cover all the information needed to document artefacts, due to such complicating factors as regional and local preference for names and issues of accessibility and affordability by museums. During my visits to various museums I found that many South African institutions have adopted nomenclature as a tool for the cataloguing of indigenous vessels without recognizing the system as such. It works for some objects in museum collections in the sense that these get identified. While the system is in some instances effective, it would need to be reviewed and adapted to be able to cover broader types of objects that have - as is the case with many indigenous collections - never been considered for continuing studies and for exhibition. It 
should be remembered that many cataloguing models used in South African museums have been adopted solely for the purpose of ensuring the safekeeping and conservation of objects in museum custody, rather than with the intention to apply a model that may inspire research and lead to the systematic gathering of information that can be made available to the public and serve educational purposes.

An object can also be given on loan and be exhibited in other institutions so that it functions in the broader context of countrywide studies, generating more detailed analyses and additional updated information. Unfortunately, the lack of cataloguing methods that provide descriptive information on the indigenous objects in South African museums means that, in most cases, museum officials do not give researchers access to the collections in their custody, as unrecorded objects might go missing, while the lack of organizational classifications concerning collections makes their safekeeping problematic.

Specifically, objects in ethnological collections have to be considered for further research in order to construct a broader foundation, including descriptive details and enough informative text to support visual digital content of the collection (Manovich 2017: 259), at least provisionally, and to avoid future misinterpretations. In addition, some artefacts in storage are in urgent need of professional care and preservation. I note that African museums tend to present themselves as fulfilling storage responsibilities, rather than as serving society and creating awareness of the collected artefacts among members of the community where they are located.

In conclusion, the cataloguing of ethnological collections requires proper planning or a strong collection management procedure, based on collaboration, technology, research, funding, and expertise to guarantee accountability for artworks present in institutions and to bring these collections under control. A museum collection that is well catalogued will result in the balanced management of diverse artefacts, whereby it is possible to regulate both exhibited objects and those in storerooms that may be considered for future exhibition. The cataloguing practice will also facilitate the updating of information related to specific objects. Unfortunately, such favourable conditions are rarely met in South African museums. I am concerned that, if the above-mentioned measures are not taken, South African museums will turn out to be un-decolonizable institutions.

Received: 17 September 2019 Finally accepted: 28 August 2020

\section{Acknowledgements}

I would like to give thanks to Iziko Museum staff members at the Social History Centre. They have been very generous, sharing valuable knowledge about their collections with me, with reference to locating and tracing artefacts in the collections. I was also given the opportunity to use the museum library and peruse South African social history documents and photographs linked to my research area, in particular the collections of indigenous artefacts assembled by anthropologists in the past. I also acknowledge Polokwane museums officials and express my appreciation for their commitment to making their collections accessible for my research. The views presented in this paper are strictly those of the author.

\section{Notes}

1 Rich White, 'Decontextualisation of the Art Object: Making Nothing Out Of Something', 2006. http://www.counterwork.co.uk/writing/decontextualisation.pdf accessed 6 June 2014.

\section{References}

Ames, M.M. (2004) 'Museums in the Age of Deconstruction', in Gail Anderson (ed) Reinventing the Museum: Historical and Contemporary Perspectives on the Paradigm Shift, 80-99, Walnut Creek, California: AltaMira Press. 
Ashworth, G. and Howard, P. (1999) European Heritage: Planning and Management, Exeter, Portland: Intellect Books.

Baca, M., Harpring, P., Lanzi, E., McRae, L. and Whiteside, A. (2006) Cataloguing Cultural Objects: A Guide to Describing Cultural Works and Their Images, Chicago: American Library Association.

Bennett, T. (1988) 'Museums and the People', in Robert Lumley (ed) The Museum TimeMachine: Putting Cultures on Display, 63-85, London: Routledge.

(2004) Pasts Beyond Memory: Evolution, Museums, Colonialism, London and New York: Routledge.

Bernard, H.R. (2006) Research Methods in Anthropology: Qualitative and Quantitative Approaches, 4th ed., Lanham, MD: AltaMira Press.

Blench, R. (2006) Archaeology, Language, and the African Past, Lanham MD: AltaMira Press.

Brain, R. (1980) Art and Society in Africa, London: Brandenburg.

Buck, R. and Gilmore, J.A. (2007) Collection Conundrums: Solving Collections Management Mysteries, Washington DC: American Association of Museums.

Burcaw, G.E. (1997) Introduction to Museum Work, 3rd ed., Walnut Creek, CA: Altamira Press.

Cabral, A. (1994) 'National Liberation and Culture', in Patrick Williams and Laura Chrisman (eds) Colonial Discourse and Post-colonial Theory: A Reader, 53-65, New York: Columbia University Press.

Case, M. (1988) 'What Registers Do All Day', in Mary Case (ed) Registrars on Record: Essays on Museum Collection Management, 12-33, Washington DC: American Association of Museums.

Césaire, A. (2000) Discourse on Colonialism, translated by J. Pinkham, New York: Monthly Review Press.

Chenhall, R.G. (ed) (1988) The Revised Nomenclature for Museum Cataloguing: A Revised and Expanded Version of Robert G. Chenhall's System for Classifying Man-Made Objects, Nashville: AASLH Press.

Chikane, R. (2018) Breaking a Rainbow, Building a Nation: A Politics behind \#MustFall Movements, Johannesburg: Picador Africa.

Collins, M. (2017) 'Nation, State, and Agency: Evolving Historiographies of African Decolonization', in Andrew W.M. Smith and Chris Jeppesen (eds) Future Imperfect: Britain, France, and the Decolonization of Africa, 17-42, London: UCL Press.

Coombes, A.E. (2003) History After Apartheid: Visual Culture and Public Memory in a Democratic South Africa, Durham, NC: Duke University Press.

Corsane, G. (2004) 'Transforming Museums and Heritage in Post-colonial and Postapartheid South Africa: The Impact of Processes of Policy Formation and New Legislation', Social Analysis, 48 (1) 5-15.

Csikszentmihalyi, M., and Rochberg-Halton, E. (1981) The Meaning of Things: Domestic Symbols and the Self, Cambridge: Cambridge University Press. 
Delsey, T. (1989) 'Standards for Descriptive Cataloguing: Two Perspectives on the Past Twenty Years', in Elaine Svenonius (ed) The Conceptual Foundations of Descriptive Cataloguing, 51-60, San Diego, CA: Academic Press.

Drayton, R. (2019) 'Rhodes Must Not Fall?: Statues, Postcolonial 'Heritage' and Temporality', Third Text: Critical Perspectives on Contemporary Art and Culture: Special issue: Exhibiting the Experience of Empire: Decolonising Objects, Images, Materials and Words, 33 (4-5) 1-16.

Dubin, S.C. (2006) Transforming Museums: Mounting Queen Victoria in a Democratic South Africa, New York: Palgrave Macmillan.

Edson, G. (1997) Museum Ethics, London: Routledge.

Fanon, F. (1961) The Wretched of the Earth, Harmondsworth: Penguin.

(1994) 'On National Culture', in Patrick Williams and Laura Chrisman (eds) Colonial Discourse and Post-colonial Theory: A Reader, 36-52, New York: Columbia University Press.

Finch, P.S. (1988) 'The Essential Collections Inventory', in Mary Case (ed) Registrars on Record: Essays on Museum Collection Management, 145-58, Washington DC: American Association of Museums.

Fox, R. (1994) The Challenge of Anthropology. Old Encounters and New Excursions, New Brunswick, London: Transaction Books.

Gell, A. (1998) Art and Agency: An Anthropological Theory, Oxford: Clarendon Press.

Giblin, J., Ramos, I. and Grout, N. (2019) 'Dismantling the Master's House: Thoughts on Representing Empire and Decolonising Museums and Public Spaces in Practice. An introduction', Third Text: Critical Perspectives on Contemporary Art and Culture: Special issue: Exhibiting the Experience of Empire: Decolonising Objects, Images, Materials and Words, 33 (4-5) 471-86.

Golding, V. (2009) Learning at the Museum Frontiers. Identity, Race and Power, Surrey: Ashgate Publishing Limited.

Goodnow, K.J., Lohman, J. and Bredekamp, J. (2006) Challenge and Transformation: Museums in Cape Town and Sydney, Paris: UNESCO.

Graburn, N. (1976) Ethnic and Tourist Arts: Cultural Expressions from the Fourth World, Los Angeles: University of California Press.

Grimshaw, A. (2001) The Ethnographer's Eye: Ways of Seeing in Modern Anthropology, Cambridge: Cambridge University Press.

Hammond-Tooke, W.D. (1997) Imperfect Interpreters: South Africa's Anthropologists, 1920-1990, Johannesburg: Witwatersrand University Press.

Hodder, I. (1996) 'The Contextual Analysis of Symbolic Meanings', in Susan Pearce (ed) Interpreting Objects and Collections, 12-8, London: Routledge.

Hooper-Greenhill, E. (1999) 'Education, Communication and Interpretation: Towards a Critical Pedagogy in Museums', in Eilean Hooper-Greenhill (ed) The Educational Role of the Museum, 3-27, 2nd ed., London: Routledge.

Hunter, E.J. and Bakewell, K.G.B. (1991) Cataloguing, 3rd ed., London: Library Association. 
ICOM (1996) The Handbook of Standards: Documenting African Collections, Paris: International Council of Museums.

(2006) Code of Ethics for Museums, Paris: International Council of Museums.

Jeffers, S.J. (2003) 'Museum as Process', Journal of Aesthetic Education 37 (1) 107-19.

Jordaan, J. (1992) The Bakoni Malapa Northern Sotho Open-Air Museum: Establishment and Management, Pietersburg (now Polokwane): Pietersburg Town Council.

Jordanova, L. (1989) 'Objects of Knowledge: A Historical Perspective on Museums', in Peter Vergo (ed) The New Museology, 22-40, London: Reaktion Books.

Karp, I. (1992) 'Introduction: Museums and Communities: The Politics of Public Culture', in Ivan Karp, Christine Mullen Kreamer and Steven D. Levine (eds) Museums and Communities: The Politics of Public Culture, 1-17, Washington, DC: Smithsonian Institution.

Karp, I., Mullen Kreamer, C. and Levine, S. D. (eds) (1992) Museums and Communities: The Politics of Public Culture, Washington DC: Smithsonian Institution Press.

Kgopa, D.M. (2003) 'The role of Pietersburg Museum in Post-apartheid South Africa', MA thesis. Johannesburg: University of the Witwatersrand.

Knell, S. (ed) (1994) Care of Collections, Leicester: Routledge.

Kreps, C. (2011) 'Changing the Rules of the Road: Post-colonialism and the New Ethics of Museum Anthropology', in Janet Marstine (ed) The Routledge Companion to Museum Ethics, 70-84, London and New York: Routledge.

Lawton, A.C. (1967) 'Bantu Pottery of Southern Africa', Annals of the South-African Museum, 49 (1) 1-440.

Llobera, J.R. (2003) An Invitation to Anthropology. The Structure, Evolution, and Cultural Identity of Human Societies, New York: Berghahn Books.

Lonetree, A. (2009) 'Museums as Sites of Decolonization: Truth Telling in National and Tribal Museums', in Susan Sleeper-Smith (ed) Contesting Knowledge: Museums and Indigenous Perspectives, 322-37, Lincoln: University of Nebraska Press.

Manovich, L. (2017) 'Cultural Data: Possibilities and Limitations of the Digital Data Universe', in Oliver Grau (ed) Museum and Archive on the Move. Changing Cultural Institutions in the Digital Era, 259-76, Berlin: De Gruyter.

McClintock, A. (1994) 'The Angel of Progress: Pitfalls of the Term "Post colonialism”', in Patrick Williams and Laura Chrisman (eds) Colonial Discourse and Post-colonial Theory: A Reader, 291-304, New York: Columbia University Press.

McKenna, G. and Patsatzi, E. (2005) SPECTRUM: The UK Museum Documentation Standard, Cambridge: Museum Documentation Association.

Memmi, A. (1991) The Colonizer and the Colonized, Boston: Beacon Press.

Mignolo, W.D. (2007) 'Delinking. The Rhetoric of Modernity, the Logic of Coloniality and the Grammar of De-coloniality', Cultural Studies 21 (2-3) 449-514.

Mignolo, W.D. and Walsh, C.E. (2018) On Decoloniality: Concepts, Analytics, Praxis, Durham, NC: Duke University Press. 
Motsamayi. M.F. (2018) 'Sotho-Tswana Difala Vessels in Selected South African Museums: Challenges in Descriptions and Catalogues', Unpublished PhD dissertation. Pietermaritzburg: University of KwaZulu-Natal.

Onciul, B. (2015) Museums, Heritage and Indigenous Voice: Decolonizing Engagement, New York: Routledge.

Pearce, S.M. (1992) Museums, Objects, and Collections: A Cultural Study, Leicester: Leicester University Press.

(1994) 'Objects as Meaning; or Narrating the Past', in Susan M. Pearce (ed) Museums, Objects, and Collections: A Cultural Study, 19-29, New York: Routledge.

Polokwane Museums (ca. 2014) Polokwane Museums [brochure], City of Polokwane: Review Printers.

Punch, K.F. (2005) Introduction to Social Research - Quantitative \& Qualitative Approaches, London: Sage.

Rassool, C. (2006) 'Community Museums, Memory Politics and Social Transformation in South Africa: Histories, Possibilities and Limit', in Ivan Karp, Corinne A. Kratz, Lynn Szwaja, Tomás Ybarra-Frausto, Gustavo Buntinx, Barbara Kirshenblatt-Gimblett and Ciraj Rassool (eds) Museum Frictions: Public Cultures/Global Transformations, 286-321, Durham: Duke University Press.

Schmiegel, K.A. (1988) 'Managing Collections Information', in Mary Case (ed) Registrars on Record: Essays on Museum Collections Management, 47-56, Washington DC: American Association of Museums.

Schofield, J.F. (1948) Primitive Pottery. An Introduction to South African Ceramics, Prehistoric and Protohistoric, Cape Town: South African Archaeological Society.

Scott, C. (2019) Cultural Diplomacy and the Heritage of Empire: Negotiating Post-Colonial Returns, London: Routledge.

Strydom, C. ¡(2017) 'The Role of National Museums in South Africa: A Critical Investigation into Iziko Museums of South Africa Focusing on the Representation of Slavery', Unpublished M.Phil. dissertation. Cape Town: University of Cape Town.

Summers, R. (1975) A History of the South African Museum: 1825-1975, Cape Town: Balkema.

Thomas, N. (2016) The Return of Curiosity: What Museums Are Good For in the 21st Century, London: Reaktion Books.

Tietze, A. (2017) A History of the Iziko South African National Gallery: Reflections on Art and National Identity, Cape Town: University of Cape Town Press.

Van Beurden, J. (2012) The Return of Cultural and Historical Treasures: The Case of The Netherlands, Amsterdam: Tropen Museum KIT Publishers.

Vergo, P. (ed) (1989) The New Museology, London: Reaktion.

Wa Thiong'o, N. (1994) 'The Language of African Literature', in Patrick Williams and Laura Chrisman (eds) Colonial Discourse and Post-Colonial Theory: A Reader, 435-56, New York, Columbia University Press.

Weil, S.E. (2000) A Deaccession Reader, Washington DC: American Association of Museums. 
Westermann, M. (2005) 'Introduction: The Objects of Art History and Anthropology', in Mariët Westermann (ed) Anthropologies of Art, vii-xxxi. Williamstown, Mass.:

Sterling and Francine Clark Art Institute.

\section{Author}

Mathodi Motsamayi

ORCID iD: https://orcid.org/0000-0002-6056-1999

URL: https://orcid.org/0000-0002-6056-1999

University of Johannesburg

South Africa

mathodi23@gmail.com

Mathodi Motsamayi is a Postdoctoral Research Fellow at the University of Johannesburg, Faculty of Art, Design and Architecture. 